\title{
ДЕРЖАВНЕ УПРАВЛІННЯ
}

УДК 351.81+339.924

DOI: 10.15587/2313-8416.2015.35857

\section{СТРАТЕГІЧНІ ПРІОРИТЕТИ 3 РОЗВИТКУ НАЦІОНАЛЬНОЇ СИСТЕМИ НАФТОГАЗОТРУБОПРОВІДНОГО ТРАНСПОРТУ}

\author{
(C) I. M. Icaєва \\ Виконано ретроспективний аналіз нормативно-правових документів які регулюють відносини України, Росії \\ та краӥн Свропейського Союзу в рамках їх енергетичних політик. Визначені стратегічні інтереси держав- \\ учасниць, і зокрема, стратегічні пріоритети державного управління розвитком національної системи наф- \\ тогазотрубопровідного транспорту
}

Ключові слова: глобалізація, Євроінтеграція, транснаціональний лани̧юг «постачальник - транзитер споживач», делібералізація, реінжиніринг, адаптація

The retrospective analysis of legal documents governing relations between Ukraine, Russia and the European Union as part of their energy policies was performed. The strategic interests of participating countries and the strategic priorities of the governance with national oil and gas pipeline transport system development in particular were designated

Keywords: globalization, European integration, transnational chain "provider - transiter - consumer", deliberalization, reengineering, adaptation

\section{1. Вступ}

Процеси видобування та постачання вуглеводневих енергоносіїв (нафта і природний газ) із Російської Федерації до країн Європи реалізується в рамках єдиного технологічного ланцюга, який включає власне виробника-постачальника ресурсу (РФ), транзитера ресурсу (Україна) та споживачів ресурсу (країни ЄС).

Всі названі вище три складові об'єктивно повинні б були бути паритетно зацікавленими в інтеграції зусиль з вироблення і реалізації енергетичної політики з iï нафто- і газотранспортною складовою, орієнтованою на спільне досягнення позитивних результатів. Необхідними складовими цієї політики для всіх держав-учасниць повинні б були передбачати такі заходи, як розвідка нових родовищ, розвиток видобувних потужностей, безпечний транзит і постачання енергоносіїв, регульована лібералізація енергетичних ринків, захист прав споживачів тощо, що сприяло б удосконаленню європейської енергетичної політики та покращанню загального енергетичного клімату в Свропі.

\section{2. Постановка проблеми}

Практика «спільної» експлуатації цього об'єкта всіма країнами-учасниками протягом 2000-2014 років продемонструвала, що спільні та узгоджені дії між ними були і $є$ відсутніми з причин наявної диференційованості їх інтересів, дезінтеграцій ресурсів та різновекторності цілей [13-17]. При цьому, ситуація не змінюється на краще навіть зараз, коли в Україні відбувається декларативне реформування національного енергетичного комплексу на засадах законодавства $\mathrm{CC}$, за яким продовжують приховуватись інтереси певних монополістичних утворень, коруп- ційних схем і сприяння державних органів детермінованим бізнес-групам. Спотворена таким чином і так недолуга енергетична політика української частини об'єкта генерує причини для стагнації всього енергетичного комплексу, введення його і його складових в кризовий стан, нарощування різноманітних міжнародних зобов'язань, які можуть спричинити поглинання стратегічних нафтогазотранспортних підприємств України аналогічними природними монополіями РФ.

Оцінюючи позиції і характерні для цих позицій інтереси країн-учасниць єдиного техніко-технологічного ланцюга, який, на жаль, не виступає об'єктом єдиного управління, слід звернути увагу на особливості розробки і реалізації енергетичної політики кожним із учасників (РФ, Україна, СС), які формуються на основі врахування їх природно-географічних умов, технікотехнологічних та фінансово-економічних можливостей.

\section{3. Літературний огляд}

Цілком очевидна взаємозалежність учасників цього складного як $з$ техніко-технологічної, так і 3 управлінсько-економічної точок зору транснаціонального об'єкта є предметом досліджень, присвячених можливостям державного управління 3 позицій удосконалення [1-12].

Незважаючи на досить широку бібліографію та детальність окремих напрямів дослідження проблем розвитку нафтогазотранспортних систем України i їх використання в якості інструменту забезпечення енергетичної безпеки та потенційного ресурсу для соціально-економічного розвитку необхідно повернутися до обговорення засад стратегічних пріоритетів державного управління цим національним багатством [15-18]. 


\section{4. Дослідження проблеми визначення страте- гічних пріоритетів}

Російська Федерація покладає в основу своєї енергетичної політики грандіозні природні запаси вуглеводневих ресурсів. За цілком справедливими твердженнями автора [18], «... Росія визначає пріоритетом створення такого енергетичного сектору, який має забезпечити своєрідний «силовий» фактор впливу на досягнення зовнішньополітичних цілей, при чому пов'язаних не тільки із просуваням інтересів енергетичного сектору. На енергетичний сектор покладається завдання нівелювання недосконалості соціальноекономічної моделі господарювння в країні шляхом гарантування бюджетних надходжень від діяльності видобувних галузей».

Україна, цілковито усвідомлюючи свою критичну залежність від імпорту вуглеводневих енергоносіїв, в формування власної енергетичної політики повинна максимально ефективно використовувати притаманні їй переваги у транзитних потужностях, наявності значних запасів природного газу, вугілля та урану, а також досі невикористаного потенціалу енергозбереження.

Для України, враховуючи іiі позиціювання як країни-споживача та транзитера, завдання має полягати в досягненні такого стану функціонування системи енергозабезпечення життєдіяльності суспільства, який забезпечуватиме спроможність країни, в умовах конкурентної боротьби, залучати енергетичні ресурси та ефективно їх перетворювати у задоволені потреби суспільства [18].

Європейський Союз вибудовує свою енергетичну політику на основі добре усвідомленого дефіциту власних енергетичних ресурсів за наявності величезного інноваційного потенціалу та одного із найбільших за ємністю світових енергетичних ринків.

Формуючи конкурентну модель організації суспільства ЄС визначає пріоритетом енергетичної стратегії обмеження можливого «силового» впливу виробників енергоресурсів. Завданнями в цьому випадку є диверсифікація джерел і маршрутів постачання енергоресурсів до $\mathrm{CC}$, а також посилення конкуренції та обмеження можливості зловживань на внутрішніх ринках.

Очевидна залежність і України, і СС від імпорту нафти і газу зумовлює певну спільність їх інтересів у зниженні енергозатратності процесів продукування валового продукту, у демонополізації ринку енергоносіїв і у конкуренції між їх постачальниками.

В зв’язку з цим, на нашу думку, головними правовими механізмами реалізації інтересів країнитранзитера, як і країн-споживачів повинні служити механізми, оформлені наступними документами:

Свропейська Енергетична хартія [19] та Договір до Енергетичної Хартії з Заключним актом [20];

Договір про заснування Енергетичного Співтовариства [21] і Протокол про приєднання України до Договору [22];

Третій Енергетичний пакет в складі п’яти нормативно-правових актів, які регулюють газову та електроенергетичну галузі СС [23], План СС «20-20-20» [24].

Інтереси ж РФ генеруються на основі цілком інших інтенцій, які, маючи цілком зрозумілу економічну складову, а в багатьох випадках i геополітичну, мотивують дії із «примушування» РФ своїх партнерів з України і ЄС до:

- підписання довгострокових контрактів купівліпродажу газу;

- перешкоджання зростанню частки спотової торгівлі на газовому ринку;

- блокування реалізації проектів $з$ диверсифікації джерел постачання енергоресурсів;

- розбудови нових трубопровідних маршрутів 3 експорту вуглеводнів російськими компаніями;

- активного спротиву процесам лібералізації та конкуренції на енергетичних ринках Свропи.

Вихід РФ з Договору до Енергетичної Хартії стало прямим свідченням цих намірів, які у 2009 р. були підкріплені ініціативою РФ під назвою «Концептуальний підхід до нової правової бази міжнародного співробітництва у сфері енергетики (цілі і принципи)», спрямованою на зміну пріоритетів Договору до Енергетичної хартії, і розробленою в інтересах вертикально-інтегрованих російських компаній і без врахування прав споживачів [22].

На тлі різновекторного цілепокладання країнучасників, спроби пошуку та обгрунтування управлінських технологій, механізмів та інструментів об'єднання інтересів учасників транснаціонального ланцюга «постачальник-транзитер-споживачі» вимагають попереднього визначення та аналізу їх стратегічних інтересів, пріоритетів, цілей і завдань 3 розвитку i функціонування національних систем трубопровідного транспорту з наступним визначенням аналогічних показників нафто газотранспортної системи України.

3 цією метою спробуємо проаналізувати енергетичні відносини між РФ, Україною та ЕС 3 позицій стратегічних інтересів останніх.

Аналізуючи відносини в рамках РФ - Украйна, неважко прийти до висновку, що, починаючи з 2000 року, РФ досить успішно реалізує політику співробітництва 3 Україною в енергетичній сфері (пріоритет в якій без сумніву належить нафтогазовому комплексу) в обмеженому двосторонньому форматі 3 метою мінімізації впливу на ці відносини СС. При цьому, політика РФ відзначається жорсткими, цілеспрямованими та послідовними діями щодо України незалежно від того, які політичні сили знаходяться при владі, в повній мірі використовуючи енергетичну залежність нашої держави для впливу на ii зовнішньополітичний курс та утримання у сфері своїх інтересів з використанням непрозорих схем поставок газу [25]. Яскравим прикладом такого впливу слід вважати так звану «газову війну» 2009 року із застосуванням «енергетичної зброї», внаслідок якої відбулося:

- зростання цін на імпортний газ для України 3 $\$ 50$ до \$425 за $1000 \mathrm{~m}^{3}$;

- укладання під диктовку РФ асиметричного довгострокового контракту купівлі-продажу газу на 2009-2019 роки разом 3 контрактом на транзит російського газу на той же період;

- формування значного дефіциту бюджету НАК «Нафтогаз України»;

- «вимивання» валютних резервів держави і зростання залежності української економіки від російського газу; 
- генерування РФ переліку пропозицій 3 поглинання активів нафтогазової галузі через створення спільних підприємств [26] і організацію спільної діяльності між суб' єктами господарювання РФ і України [27];

- намагання РФ нівелювати можливості України 3 залучення іноземних інвестицій у пошук і розробку нових вітчизняних родовищ вуглеводнів з метою збереження монопольної залежності від Росії [28].

Відносини в рамках $Є C$ - Украйна 32005 року регулюються Договором про заснування Енергетичного Співтовариства i Меморандумом «Про взаєморозуміння й співробітництво в енергетичній сфері між Україною і СС», головною метою яких було створення єдиного європейського ринку електроенергії та газу, який функціонує за уніфікованими та гармонізованими правилами з інтеграції і лібералізації ринків європейських країн.

Меморандум «Про взаєморозуміння й співробітництво в енергетичній сфері між Україною і ЄС» $є$ важливим етапом з ії приєднання до Договору, а газові конфлікти 2006 і 2009 років мотивували ЄС до зміни ситуації в сфері енергетичної безпеки Свропи через підписання Спільної Декларації з реконструкції і модернізації української ГТС (Брюссельська декларація) [29]. Цим документом була визначена програма кардинальної реорганізації газової галузі України на засадах прозорості, розвитку конкуренції, безпеки газопостачання, створення в галузі інвестиційно-привабливих умов і започатковані конкретні кроки $з$ адаптації української нафтогазової галузі до норм і правил $\mathrm{CC}$.

Якби Україною були здійснені заплановані реформ, то фінансові інституції $Є С$ взяли б на себе функцію залучення інвестицій у реконструкцію української ГТС на суму приблизно в 3-5 млрд. доларів, що майже вчетверо менше від вартості «Південного потоку».

На виконання Договору-Меморандуму Парламентом України у 2010 році було ухвалено Закон «Про засади функціонування ринку природного газу», який частково адаптував українське законодавство до відповідних Директив ЄC шляхом створення відповідних державних регулювань щодо рівного доступу суб'єктів газового ринку до Єдиної газотранспортної системи та розмежування функцій 3 видобутку, транспортування, розподілу і поставок газу. Головним же результатом виконання завдань Договору-Меморандуму слід вважати приєднання України до Договору 1 лютого 2011 року [30].

При цьому, однак, входження України до енергетичного простору ЄС вимагає попередньої імплементації вітчизняного законодавства шляхом затвердження Україною необхідної кількості підзаконних актів, покликаних удосконалити Закон «Про засади функціонування ринку природного газу» та «Порядок доступу до Єдиної газотранспортної системи України», які були розроблені 3 метою імплементації європейського Регламенту 1775/2005.

Незаперечним пріоритетом відносин СС Україна $є$ реформування НАК «Нафтогаз України» в сучасну корпоративну бізнес-структуру 3 високою якістю управління, яка при сьогоднішній непрозорій структурі i нечітко сформульованих державних інтересах займалась перерозподілом фінансових i матеріальних ресурсів держави на користь провладних бізнесів. Зволікання ж з реформуванням НАК і виокремлення ГТС як самостійної юридичної особи, приводить до того, що без фінансової та юридичної самостійності ДК «Укртрансгаз» не зможе досягти фінансової стабільності та залучити потрібні кошти інвесторів на модернізацію магістральних газопроводів і підземних сховищ газу.

Однак, прийнятий 13 квітня 2012 року Закон «Про внесення змін до Закону України «Про трубопровідний транспорт» (щодо реформування нафтогазового комплексу)" є декларативним і не наближає українське законодавства до норм і правил ЄС так як надав право на реорганізацію НАК «Нафтогаз України» українському Уряду, економічні і політичні інтереси якого залишаються непрозорими. Тому імплементація енергетичного законодавства ЄC в Україні відбувається в імітаційному режимі, в зв'язку з чим замість розвитку конкуренції, забезпечення захисту прав споживачів та інвесторів, продовжується практика розробки все нових і нових корупційних схем, які базуються на зрощенні влади і крупного бізнесу.

Не дивлячись на це, вступ України до Енергетичного Співтовариства все таки відкриває певні можливості для іiі повноцінного входження до єдиного енергетичного простору СС, а адаптація нормативноправової бази сприятиме гармонізації газових ринків України та СC, конкуренції і безпеці поставок газу, надійності його транзиту до країн Свропи, посиленню позицій України в перемовинах 3 країноюпостачальником.

Відносини в рамках $C C-P \Phi$ грунтувались на підписаній ще у 1994 році Угоді про партнерство та співробітництво між Росією та ЄС. Однак, впродовж останніх років реальним механізмом співпраці в енергетичній сфері став Енергетичний діалог РФ - СС, який стартував у 2000 році на Спільному саміті в Парижі. В рамках цього діалогу організована робота тематичних груп, груп високого рівня і Постійної ради партнерства РФ-СС на рівні міністрів енергетики. Головною метою діалогу є забезпечення взаємної енергобезпеки та взаємовигідного співробітництва між бізнес-структурами сторін.

Слід однак наголосити на тому, що сьогодні механізм діалогу не забезпечує ефективного використання потенціалу взаємовідносин РФ-СС, які з кожним роком все більше формалізуються і не сприяють вирішенню практичних завдань. Це спричинено тим, що інтеграції країн $С С$ не відповідає інтересам РФ в зв'язку з тим, що остання (як і у випадку з Україною) надає перевагу вирішуванню будь-яких питань у двосторонньому форматі з кожною країною ЄС окремо.

Така індивідуалізація політики РФ чітко окреслилась і отримала адекватну реакцію СС у вигляді затвердження в 2009 році Європарламентом і Радою Європи пакета документів, якими встановлені головні принципи третього етапу лібералізації ринків електроенергії і природного газу СС. Цими документами було передбачено можливість і обов'язок обмеження інвестиційної активності компаній-монополістів, які не забезпечили відокремлення функцій видобутку, 
транспортування та постачання, в енергетичну інфраструктуру ЄС. Таким чином, це стало серйозною загрозою втіленню стратегічних інтересів РФ з придбання енергетичних активів $\mathrm{CC}$, а також будівництва нових газопроводів.

Ця ситуація обумовила загострення протиріч у відносинах РФ-СС, що, однак, не стало на заваді продовження співпраці 3 окремими країнами $С С$ у реалізації економічно необгрунтованого i політично вмотивованого проекту «Південний потік», який $є$ для РФ стратегічним пріоритетом [25].

Слід вказати, що газопроводи «Північний потік» i «Південний потік», за існуючої практики укладання довгострокових контрактів, можуть підвищити узалежнення європейських споживачів від російського газу, що створює реальну загрозу диверсифікації i конкуренції на ринку СС та суперечить енергетичній політиці ЄС.

Конкретизуючи стратегічні інтереси країнучасників ланцюга «видобування-постачання - транзит - споживання» вуглеводневих ресурсів, прийдемо до фіксації наступних трьох переліків, виконаних в порядку формування ланцюга:

1. Стратегічні інтереси РФ.

1.1. Бажання отримання контролю над експортними маршрутами нафти і природного газу з РФ до СС 3 метою нарощування доходів і посилення політичного впливу, яке реалізується шляхом блокування диверсифікаційних проектів СС і монополізації поставок цих ресурсів з країн Центральної Азії.

1.2. Деліберелізація енергетичного ринку $\mathrm{CC} 3$ метою виходу РФ на кінцевих споживачів в країнах $€ \mathrm{C}$, нарощування частки своїх енергоносіїв і встановлення монопольних цін шляхом протидії впровадженню документів «Третього пакету і збереження практики укладання довгострокових контрактів.

1.3. Максимально можливе нівелювання впливу України в перемовинах 3 СС через дискредитацію України і іiі політики в очах $\mathrm{CC}$ та виключення іiі із технологічного ланцюга «видобуток - постачання споживання» вуглеводневих ресурсів.

1.4. Встановлення контролю над нафто- і газотранспортними системами України, внутрішнім ринком вуглеводневої сировини та примусового втягування України до Митного союзу.

1.5. Гальмування i/aбо повне припинення процесу адаптації і наступної інтеграції України до єдиного енергопростору СС з метою збереження статус-кво у внутрішньому монополізованому і непрозорому ринку енергоресурсів на основі використання чинника глибокої енергозалежності та вузько кланових інтересів близьких до влади промислово-фінансових груп.

\section{2. Стратегічні інтереси України.}

2.1. Мінімізація політичних, економічних і соціальних наслідків дефіциту вуглеводневих ресурсів і вирішення цієї проблеми в недалекому майбутньому.

2.2. Реформування галузевої складової на правових засадах енергетичних пакетів СС з метою залученню інвестицій, зниження залежності від поставок РФ, посиленню позицій України в процесі перемовин з РФ.

2.3. Масштабна розробка i впровадження проектів енергозбереження, енергозберігаючих технологій, використання альтернативних джерел енергії, збільшення видобутку природного газу (включаючи всі види нетрадиційного), будівництва LNG- i CNG-терміналів та диверсифікації країнпостачальників.

2.4. Кардинальний реінжиніринг процесів поставок і продажу газу РФ споживачам $Є С$, згідно 3 яким споживачі ЄС будуть отримувати газ від постачальника (ВАТ «Газпром») на кордоні РФ-Україна з одночасним укладанням контрактів на транзит з українським газотранспортним оператором, що поглибить співпрацю в рамках Україна-СС і ліквідує двосторонній формат РФЄС $з$ переходом до тристороннього РФ-Україна-СС i мінімізує транзитні ризики.

2.5. Синхронізація нафто- i газотранспортних систем України з відповідними мережами СС з метою зростання конкуренції на внутрішньому ринку, ліквідації монопольної залежності від поставок РФ, зниженню цін для споживачів, оптимізації ефективності використання українських підземних сховищ газу для організації ринку спотової торгівлі у країнах ЄC.

2.6. Забезпечення прозорого тристороннього механізму «раннього попередження» про проблеми в сфері енергобезпеки ЄС по всьому ланцюгу «видобування-постачання - транзит - споживання».

2.7. Збереження ТTC України в державній власності та державним контролем до моменту їх реформування відповідно з вимогами законодавства СС та залучення європейських i/або американських компаній до їх приватизації із збереженням за державою контрольних пакетів акцій.

2.8. Мінімізація обсягів закупівлі природного газу i нафти в РФ 3 метою подолання монопольної залежності України від російських енергоносіїв шляхом виконання реструктуризації енергоринку за принципами законодавства ЄС, кардинального зменшення енергоємностї ВВП, збільшення залучення іноземних інвестицій для видобутку власного природного газу і нафти.

\section{3. Стратегічні інтереси $Є C$.}

3.1. Розвиток мережі LNG-терміналів і участь у формуванні глобального LNG-ринку.

3.2. Створення альтернативних джерел i маршрутів поставок газу з Каспійського регіону в рамках «Південного коридору», який охоплює такі ТТС, як Nabucco, «Трансадріатичний газопровід», газопровід Туреччина-Греція-Італія, Транскаспійський газопровід та ін. для залучення ресурсів Центральної та Середньої Азії.

3.3. Збільшення на ринку СС частки спотової торгівлі газом 3 переглядом моделі ціноутворення на основі прив'язки вартості газу до ціни нафтопродуктів.

3.4. Активізація конкуренції, посилення антимонопольних заходів та обмеження інвестицій в енергетичну інфраструктуру з боку вертикально-інтегрованих європейських енергетичних компаній, співвласником яких є ВАТ «Газпром» (РФ).

3.5. Інтеграція окремих газопроводів у єдину газотранспортну систему ЄС з метою створення умов для розширення палітри вибору постачальників газу, підвищення надійності газопостачання, оптимізації 
режимів роботи ГТС, зниження залежності СС від третіх країн.

Цілком очевидно, що сформульовані нами вище переліки стратегічних інтересів сторін-учасниць процесу транспортування вуглеводнів носять аналітичноумоглядний характер (особливо щодо таких складових, як РФ і (С). Однак, стратегічні інтереси України дозволяють прийти до висновку, що енергетичні політики РФ та України сьогодні є несумісними з принципами реформування енергетичного ринку СС в зв'язку з тим, що як в РФ, так i в Україні переважають адміністративні методи державного управління та намагання закріпити за державними і окремими бізнесструктурами монопольних прав і домінування на енергетичних ринках цих країн, замість удосконалення ринкових механізмів державного регулювання та лібералізації їх економік загалом та складових енергетичного сектору зокрема.

Отже, головні проблеми і перепони процесам інтеграції української нафтогазотранспортної системи до європейських мереж генеруються системними протиріччями між інтересами діючих в РФ і Україні державних влад, які сьогодні спрямовані на обслуговування потреб крупного бізнесу шляхом створення умов для отримання представниками останнього монопольної ренти через використання корупційних схем i механізмів. Без вирішення цих системних протиріч і збереженні статус-кво у відносинах ланцюга РФ - Україна - СС належна, економічно ефективна i технологічно безпечна координація діяльності суб'єктів господарювання є неможливою, а це, в свою чергу, продовжує залишати сферу гарантованого енергозабезпечення як України, так і ЄС високо ризиковою та конфліктогенеруючою.

Отже, ситуацію, яка склалася на сьогодні, можна охарактеризувати словами старшого наукового співробітника британського Королівського інституту міжнародних відносин (Chatham House) Джеймса Шерра - сьогодні «Україна затиснута між вимогами Свропейського Союзу та Росії» [31].

\section{6. Висновки}

На основі сформульованих вище стратегічних інтересів України можна виділити і сформулювати перелік пріоритетних цілей та завдань з розвитку і функціонування національної системи трубопровідного транспорту, які в подальшому повинні стати пріоритетами державного управління і регулювання його діяльності:

- забезпечення результативного і ефективного функціонування вітчизняної системи нафтогазових ТTC на користь українського суспільства;

- перегляд і удосконалення системи державного управління і регулювання діяльністю галузі;

- реформування структури і системи управління транспортною складової галуззі;

- організаційно-юридична гармонізація та інтеграція суб'єктів господарської діяльності РФУкраїна-СС;

- інноваційний управлінсько-організаційний, фінансово-економічний i технічніко-технологічний розвиток суб' єктів господарської діяльності ланцюга РФ-Україна-СС.
Найбільш пріоритетним завданням 3 цього переліку слід вважати саме завдання з удосконалення державного управління i регулювання діяльністю суб' єктів господарювання цього сектору національного господарства.

При цьому, зусилля держави повинні спрямовуватись не стільки на надійне забезпечення національного господарства енергоресурсами та ефективне використання потужного потенціалу нафтогазотранспортних мереж (як технологічна мета), скільки на позитивні наслідки цієї діяльності для всього українського суспільства (соціально-економічна мета).

Відповідно до затвердженої ще 14.09.2000 року Указом Президента України №1072/2000 [32] «Програми інтеграції України до Європейського Союзу», Україні слід адаптувати до нормативного простору СС національні закони та запровадити стандарти СС щодо якості та надійності енергопостачання 3 врахуванням необхідності зменшення впливу держави в цьому секторі економіки, лібералізації ринків енергоносіїв, приваблення інвестицій, зменшення енергомісткості економіки, а також створення адекватного цим завданням регуляторно-управлінського простору.

Цілком очевидно, що головним пріоритетом державного регулювання i управління діяльністю вітчизняних нафтогазотранспортних мереж також повинні бути соціально-економічними, а всі інші показники техніко-технологічного, зовнішньо- i внутрішньополітичного та глобалізаційного характеру, слід вважати вторинними. Це, звичайно, вимагатиме як масштабного перегляду i реформатування діючого нормативно-правового поля, так i перегляду традиційних критеріїв державного регулювання i управління цим стратегічно важливим сектором національної економіки.

\section{Література}

1. Вуглеводневі колізії - Газові магістралі як єдина система [Електронний ресурс] / Новинар. - Режим доступу: novynar.com.ua

2. Гуцал, А. Чи стане газова труба «Вишневим садом» [Текст] / А. Гуцал // Дзеркало тижня. - 2001. - № 1(325). 2001-01-06-2001-01-12.

3. Діяк, I. В. Проекти приватизації ГТС України [Текст] / І. Д. Діяк // Собственность. - 2002. - № 1.

4. Імпортно-експортна політика України в енергетичній сфері: стратегічні пріоритети [Текст] / за заг. ред. А. Шевцова. -Регіональний філіал Національного інституту стратегічних досліджень у м. Дніпропетровську, 2005. - 126 с.

5. Гончар, М. М. Газові кризи та обхідна стратегія Росії: взаємозв'язок і обумовленість [Текст] / М. М. Гончар / Економічний часопис. - 2000. - Т. XXI, № 11-12. - С. 9-12.

6. Баррозу: Газова війна завдала шкоди зближенню України з СС / [Електронний ресурс] / Українська Правда. 06.01.2009. - Режим доступу: http://www.pravda.com.ua/news/ 2009/01/8/3661986/

7. Ященко, А. Газова війна: хто перемагає і що далі? або Про що мовчить Газпром [Електронний ресурс] / А. Ященко, К. Лесів. - Інформаційне агентство УНІАН. 08.01.2009. - Режим доступу: http://www.unian.net/ukr/ news/news- 293901.html

8. Сафарян, Э. Гордиев узел энергоресурсов Каспия [Текст] / Э. Сафарян // Азия и Африка сегодня. - 2004. - № 9.

9. Симиндей, В. В. “Латвийский узел” Балтийского транзита [Текст] / В. В. Симиндей // МЭ и МО. - 2001. № 4. - C. 107-112. 
10. Москва и Киев снова лишили Европу газа [Електронний ресурс] / РБС «Кризис». 14.01.2009. - Режим доступу: http://krisis.in.ua/?p=1565

11. Матюхіна, Н. Guardian: нова газова війна стає більш реальною [Електронний ресурс] / Н. Матюхіна // ВВС. Україна. - Режим доступу: http://www.bbc.co.uk/ukrainian/press_review/2013/10/131030_fo reign press rl.shtml

12. Шурхало, Д. Україна і Росія - за крок від нової газової війни [Електронний ресурс] / Д. Шурхало // Режим доступу:

http://www.radiosvoboda.org/content/article/25152067.html

13. Газовий ринок в Україні: Аналітична доповідь центру Разумкова [Текст] / Національна безпека та оборона. 2008. - № 8. - C. 18-29.

14. Енергетична безпека України: чинники впливу, тенденції розвитку [Текст] / за ред. М. П. Ковалик. - НАН України; АТ "Укренергозбереження". К., 1998. - 159 с.

15. Паливно-енергетичний комплекс України: готовність до євроінтеграції [Текст] / Національна безпека і оборона. - Київ. - 2002. - № 9 .

16. Люта, Н. В. Стратегічний аналіз нафтотранспортної системи України як складного об'єкта промислової логістики [Текст] / Н. В. Люта // Соціальноекономічні дослідження в перехідний період. - 2006. Вип. 5 (61). - С. 83-88.

17. Крижанівський, Є. І. Аналіз та оцінка світового досвіду 3 управління міжнаціональними магістральними трубопровідними системами [Текст] / Є. I. Крижанівський, І. Л. Боднарук, Н. В. Люта, В. П. Петренко // Економіка та управління в нафтовій і газовій промисловості. - 2010. № 2. - С. 40-44.

18. Суходоля, О. М. Теоретико-методологічні засади забезпечення енергетичної безпеки України [Текст] / О. М. Суходоля // Стратигічні пріоритети. - 2014. № 2 (31). - С. 129-139.

19. Заключний документ Гаазької конференції 3 Європейської Енергетичної Хартії від 17.12.1991 року [Електронний ресурс] / МЕГА-НаУ. - Режим доступу : http://zakon.nau.ua/doc/?code=995_061

20. Договір до Енергетичної Хартії та Заключний акт до неї. Договір ратифіковано Законом N 89/98-ВР (89/98-ВР) від 06.02.98 [Електронний ресурс] / Рада Закон. - Режим доступу: http://zakon4.rada.gov.ua/laws/show/995_056

21. Договір про заснування Енергетичного співтовариства / [Електронний ресурс] Рада Закон. - Режим доступу: $\quad$ http://zakon4.rada.gov.ua/laws/show/994_926/ print 1295450391976624

22. Протокол про приєднання України до Договору про заснування Енергетичного Співтовариства [Електронний pecypc] / Рада Закон. - Режим доступу: http://zakon2.rada.gov.ua/laws/show/994_a27

23. Гудков, И. В. Третий энергетический пакет Европейского союза [Текст] / И. В. Гудков // Нефть, газ и право. 2010. - № 3. - C. 58-66.

24. Europe: EU's strategies to reach the «20-2020 Targets» [Електронний ресурс] / Carbon, Renewable Energy and Sustainability. - Режим доступу http://agneyablog.wordpress.com/2011/05/04/europe-eu'sstrategies-to-reach-the-"20-20-20-targets"/

25. Українсько-російські взаємовідносини в енергетичній сфері: стан, новітні тенденції розвитку та перспективи [Текст] / Центр Разумкова. Національна безпека i оборона. -2010 . - № 6. - С. 2-34.

26. Пресс-релиз Управления информации ОАО «Газпром» [Електронний ресурс] / Сайт ОАО «Газпром». - Режим доступу: http://www.gazprom.ru

27. «Лукойл» і «Чорноморнафтогаз» спільно видобуватимуть вуглеводні / [Електронний ресурс] / Інтернет- видання «Українська енергетика». - Режим доступу: http://uaenergy.org/post/16708

28. Створення стратегічних резервів нафти та нафтопродуктів в Україні: стан, проблеми, пошук шляхів вирішення на основі міжнародного досвіду [Текст] / Центр Разумкова. Національна безпека і оборона. - 2007. - № 4. - С. 22.

29. Спільна заява. Спільна СС-Україна міжнародна конференція щодо модернізації газотранзитної системи України від 23 березня 2009 року (Брюссельська декларація) [Електронний ресурс] / Рада Закон. - Режим доступу: http://zakon4.rada.gov.ua/laws/show/994_989

30. Шостий спільний звіт Україна-СС [Електронний ресурс] / Інтернет-видання «Українська енергетика» 27 березня 2012. - Режим доступу: http://ua-energy.org

31. Стан відносин України з СС $є$ руйнівним [Електронний ресурс] / КиївПост. UA. - Режим доступу: http://www.kyivpost.ua/politics/article/dzhejms-sherr-stanvidnosin-ukrayini-z-yes-ye-rujnivnim-37161.html

32 Указ Президента України «Про Програму інтеграції України до Європейського Союзу» [Текст] / від 14 вересня 2000 року №1972/2000.

\section{References}

1. Hydrocarbon conflicts - gas pipelines as a single system. Available at: novynar.com.ua

2. Hutsal, A. (2001). Chy stane gazova truba "Vyshnevym sadom" [Will gas pipe "Cherry Garden"]. Mirror Weekly, 1 (325).

3. Diyak, I. V. (2002). Proekty pryvatyzatsiyi GTS Ukrayiny [Projects privatization of Ukraine's gas transport system]. Sobstvennost', 1 .

4. Shevtsov, A. (Ed.) (2005). Importno-exportna polityka Ukrayiny $\mathrm{v}$ energetychniy sferi: stratehichni priorytety [Importexport policy of Ukraine in the energy sector: strategic priorities]. Dnipropetrovs'k: Regional filiation of the National Institute for Strategic Studies, 126.

5. Honchar, M. M. (2000). Gazovi kryzy ta obhidna strategiya Rosiyi: vzayemozvyazok i obumovlenist' [Gas crisis and bypass strategy of the Russia: correlation and predetermination]. Economical journal, XXI (11-12), 9-12.

6. Barroso: Gasova viyna zavdala shkody zblyzhennyu Ukrayiny z EU [Gas war has harmed the rapprochement of Ukraine with the EU]. Ukrayins'ka Pravda. 06.01.2009. Available at: http://www.pravda.com.ua/news/2009/01/8/3661986/

7. Yaschenko, A., Lesiv, K. Gasova viyna: hto peremagaye i scho dali? abo pro scho movchyt' Gasprom [Gas war: who wins and what next? or What about Gazprom is silent]. UNIAN 08.01.2009. Available at: http://www.unian.net/ukr/news/news293901.html

8. Safaryan, E. (2004). Hordiyev uzel energoresursov Kaspiya [Gordian knot of Caspian energy resources]. Asia and Africa today, 4.

9. Simindey, V. V. (2001). "Latviyskiy uzel" Baltiyskogo transita ["Latvian knot" of the Baltic transit]. IE and IR, 4, $107-112$.

10. Moskva i Kiev snova lishyli Evropu gaza [Moscow and Kiev again deprived of gas to Europe]. Crisis. 14.01.2009. Available at: http://krisis.in.ua/?p=1565

11. Matuhina, N. Guardian: nova gazova viyna staye bil'sh real'noyu [New gas war becomes more real] BBC. Ukraine. Available at: http://www.bbc.co.uk/ukrainian/press_review/2013/10/131030_foreign_press_rl.shtml

12. Shurkhalo, D. Ukrayina i Rosiya - za krok vid gazovoyi viyny [Ukraine and Russia are from a step of a new gas war]. Radiosvoboda. Available at: http://www.radiosvoboda.org/ content/article/25152067.html

13. Gazovyi rynok v Ukrayini: analitychna dopovid' tsentru Razumkova [Gas Market in Ukraine: analytical report of Razumkov Centre] (2008). National Security and Defense, 8, $18-29$. 
14. Kovalyk, M. P. (Ed.) (1998). Energetychna bezpeka Ukrayiny: chynnyky vplyvu, tendentsiyi rozvytku [Energy Security of Ukraine: influence factors and development trends]. Kyiv, 159.

15. Palyvno-energetychnyi komplex Ukrayiny: gotovnist' do yevrointegratsiyi [Fuel and Energy Complex of Ukraine: Readiness for European Integration] (2002). National Security and Defense, 9.

16. Luta, N. V. (2006). Strategichnyi analiz naftotransportnoyi systemy Ukrayiny yak skladnogo obyekta promyslovoyi logistyky [Strategic analysis of the oil transportation system of Ukraine as a complex object of industrial logistics]. National Academy of Sciences of Ukraine. L'viv, 83-88.

17. Kryzhanivskyi, Ye. I., Bodnaruk, I. L., Luta, N. V., Petrenko, V. P. (2010). Analiz ta otsinka svitovogo dosvidu $\mathrm{z}$ upravlinnya mizhnatsional'nymy magistral'nymy truboprovidnymy systemamy [Analysis and evaluation of the world experience in international main pipeline systems managing]. Economics and management in the oil and gas industry, 2, 40-44.

18. Sukhodolya, O. M. (2014). Teoretyko-metodologichni zasady zabezpechennya energetychnoyi bezpeky Ukrayiny [Theoretical and methodological principles of providing energy security of Ukraine]. Strategic Priorities, 2 (31), 129-139.

19. Zaklyuchnyi dokument Gaaz'koyi konferentsiyi z Yevropeis'koyi energetychnoyi khartiyi vid 17.12.1991 roku [Final Document of the Hague Conference on the European Energy Charter from 17.12.1991]. Available at: http://zakon.nau.ua/doc/?code=995_061

20. Dogovir do Energetychnoyi Khartiyi ta Zaklyuchnyi akt do neyi. Dogovir ratyfikovano Zakonom № 89/98-VR (89/98BP) vid 06.02.1998. [The Energy Charter Treaty and its Final Act. The treaty was ratified by Law № 89/98-VR on 06/02/98]. Available at: http://zakon4.rada.gov.ua/laws/show/995_056

21. Dogovir pro zasnuvannya Energetychnogo spivtovarystva [Treaty establishing the Energy Community]. Available at: http://zakon4.rada.gov.ua/laws/show/994 926/print1295450391976624

22. Protokol pro pryyednannya Ukrayiny do Dogovoru pro zasnuvannya Energetychnogo spivtovarystva [Protocol on Ukraine's accession to the Treaty establishing the Energy Community]. Available at: http://zakon2.rada.gov.ua/laws /show/994_a27
23. Hudkov, I. V. (2010). Tretiy energeticheskiy paket Yevropeyskogo souza [Third Energy Package of the European Union]. Oil, gas and low, 3, 58-66.

24. Europe: EU's strategies to reach the «20-2020 Targets». Available at: http://agneyablog.wordpress.com/ 2011/05/04/europe-eu's-strategies-to-reach-the-“20-20-20targets"

25. Razumkov Centre (2010). Ukrayins'ko-rosiys'ki vzayemovidnosyny $\mathrm{v}$ energetychniy sferi: stan, novitni tendentsiyi rozvytku ta perspektyvy [Ukrainian-Russian relations in the energy sector: state, newest development trends and prospects]. National Security and Defense, 6, 2-34.

26. Press-reliz Upravleniya informatsii OAO "Gazprom" [Press Release of Information administration OJSC "Gazprom"] Available at: http://www.gazprom.ru

27. "Lukoil" i "Chornomornaftogaz" spil'no vydobuvatymut' vuglevodni ["Lukoil" and "Chornomornaftogaz" will mining hydrocarbons in conjunction]. Available at: http://uaenergy.org/post $/ 16708$

28. Razumkov Centre (2007). Stvorennya strategichnyh rezerviv nafty ta naftoproduktiv $\mathrm{v}$ Ukrayini: stan, problemy, poshuk shlyahiv vyrishennya na osnovi mizhnarodnogo dosvidu [The strategic reserves creation of oil and oil products in Ukraine: state, problems and searching solutions ways based on international experience]. National Security and Defense, 4, 22.

29. Spil'na zayava. Spil'na EU - Ukrayina mizhnarodna konferentsiya shchodo modernizatsiyi gazotranzytnoyi systemy Ukrayiny vid 23 bereznya 2009 roku (Brussel's'ka deklaratsiya) [Joint Statement. Joint EU-Ukraine International Conference on modernization of Ukraine's gas transit system of March 23, 2009 (Brussels Declaration)]. Available at: http://zakon4.rada.gov.ua/ laws/show/994_989

30. Shostyi spil'nyi zvit Ukrayina - EU [The sixth joint report by the Ukraine-EU]. March 27, 2002. Available at: http://ua-energy.org

31. Stan vidnosyn Ukrayiny $\mathrm{z}$ EU ye ruynivnym [Relations state between Ukraine and EU is destructive]. Available at: http://www.kyivpost.ua/politics/article/dzhejms-sherrstan-vidnosin-ukrayini-z-yes-ye-rujnivnim-37161.html

32. Ukaz Prezydenta Ukrayiny "Pro Programu integratsiyi Ukrayiny do Yevropeys'kogo Soyuzu" vid 14 veresnya 2000 roku № 1972/2000 [Decree of the President of Ukraine "About Program of Ukrainian integration to the European Union" of September 14, 2000 \# 1972/2000].

\section{Рекомендовано до публікації д-р наук з держ. управління Шаптала О. С.} Дата надходження рукопису 05.12.2014

Ісасва Ірина Миколаӥвна, експерт з поступового виведення з обігу застарілих технологій освітлення, Програма розвитку ООН Глобальний екологічний фонд, Трансформація ринку в напрямку енергоефективного освітлення, вул. Урицького, 35, м. Київ, Україна, 03035 